"This is the peer reviewed version of the following article: [Drew, J. \& Dollery, B.E. 2016, 'Hired guns:

Local government mergers in New South Wales and the KPMG modelling report', Australian Accounting Review.], which has been published in final form at

[http://onlinelibrary.wiley.com/journal/10.1111/(ISSN)1835-2561 ]. This article may be used for noncommercial purposes in accordance with Wiley Terms and Conditions for Self-Archiving." 


\title{
Hired Guns: Local Government Mergers in New South Wales and the KPMG Modelling Report
}

\begin{abstract}
Across the developed world, including Australia, public policymaking now rests heavily on commissioned reports generated by for-profit consultants, contrasting starkly with the earlier customary reliance on the civil service to provide informed policy advice to political decision makers. Dependence on commercial consultants is problematic, especially given the moral hazards involved in 'hired guns' providing support for policy 'solutions' desired by their political paymasters. This paper provides a vivid illustration of the some of the dangers flowing from the use of consultants by examining the methodology employed by KPMG in its empirical analysis of the pecuniary consequences of proposed municipal mergers as part of the New South Wales' (NSW) Government's Fit for the Future local government reform program. We show that the KPMG (2016) modelling methodology is awash with errors which render its conclusions on the financial viability of the NSW merger proposals fatally flawed.
\end{abstract}

\section{Introduction}

Halligan (1995) advanced the notion of 'policy advisory systems' as a conceptual tool for interpreting the sources of policy adyice relied on by public agencies in the policy-making process. Craft and Howlett (2013, p.187) have observed that policy advisory systems 'arise in almost every instance of decision-making whereby governments receive advice not just from professional analysts in their employ or from outside groups, but also from a range of other actors, from think tanks and lobbyists, but also from partisan political advisors, scientific, technical and legal experts, and many others both inside and outside of government'. A substantial scholarly literature has evolved around the examination of policy advisory systems, which includes an Australian strand (see, for instance, Weller and Stevens, 1998).

While the empirical analysis of the supply of policy advice and its 'externalization' has attracted some attention from researchers (Bevir and Rhodes, 2001), unfortunately comparatively little is known about policy advice emanating from the commercial consulting industry, sometimes termed 
the 'invisible public sector' (Boston, 1994; Speers, 2007; Howlett and Migone, 2013; Vesely, 2013), despite its growing dominance in many areas of public policymaking, including Australian local government. In particular, empirical scholars of contemporary Australian local government policy making have virtually ignored the positive analysis of the quality of technical reports by for-profit consultant companies, with the notable exception of the Drew, Kortt and Dollery (2013) analysis of Deloitte Access Economics' (2011) Local Government Structural Reform in Tasmania.

Although the paucity of analysis into the quality of consultant reports may be explained by the difficulties involved in its assessment (see, for example, Gregory and Lonti, 2008), questions of quality nonetheless remain paramount given the pivotal importance of consultant reports in policy formulation by public agencies. The present paper seeks to address the lack of empirical analysis on the quality of commercial consultant technical reports on Australian local government policymaking by critically examining KPMG's (2016) Outline of Financial Modelling Assumptions for Local Government Merger Proposals, which was commissioned by the New South Wales (NSW) Government.

It is worth noting at the outset that concern over the growing use of for-profit commercial consulting as a major or even sole source of policy advice should be tempered by reflecting on 'counterfactual' alternatives. While in an ideal world 'frank and fearless' policy advice would be offered by highlytrained and impartial public sector bureaucrats unencumbered by bias of any kind and unmoved by the 'moral hazards' facing their commercial counterparts, a substantial literature on government failure, including 'bureaucratic failure', suggests an alternative view (see, for example, Wallis and Dollery 1999; Mueller 2003; Dolfsma 2013; for surveys of the government failure paradigm). In particular, it has been argued that bureaucratic failure may be pervasive and policy advice may be less disinterested and technically sound than commonly assumed (Wolf, 1989). If this is indeed the case in contemporary government departments and public agencies, then 'outsourced' policy advice may be preferable to its 'in-house' counterpart. 
KPMG (2016) sets out in detail the methodology employed in KPMG's (2015) Local Government Reform: Merger Impacts and Analysis, prepared for the NSW Government, which computed the financial benefits and costs which would purportedly flow from the proposed compulsory council consolidation in the NSW Government's Fit for the Future local government reform process. Under this program, the Baird Government has proposed 35 council mergers across both metropolitan and country NSW local government (Abelson and Joyeux, 2015; Drew and Dollery, 2014c; 2015).KPMG's (2016) Outline of Financial Modelling Assumptions for Local Government Merger Proposals plays a critical role in the Baird Government's forced amalgamation program since it sets out the only publicly available detail for the basis on which KPMG calculated the purported financial advantages attached to the specific council mergers proposed by the Baird Government. If KPMG (2016) can be shown to contain material error which renders the estimated financial advantages of particular proposed municipal mergers invalid, then this seriously undermines the fiscal foundations of the overall amalgamation program. Moreover, the delegated agents of the Boundary Commission (which is the body charged by statute to evaluate amalgamation proposals) relied almost entirely on the KPMG modelling in making their recommendations to the Minister regarding whether the proposed amalgamations should proceed. Whether it was reasonable to place reliance on the KPMG modelling is now a matter being argued before the Courts by councils opposing the forced amalgamations (Sansom, 2016).

Over the past few decades, every Australian state and territory administration has implemented forced mergers, with the sole omission of Western Australia, where the Barnett Government recently and unsuccessfully sought to impose compulsory council consolidation upon reluctant Perth councils. The Baird Government's controversial Fit for the Future forced amalgamation program is thus by no means unusual in Australian local government milieu nor is its reliance on for-profit 
consultants KPMG at all uncommon (Dollery, Grant and Kortt, 2012). Indeed, in 2004 the (then) Carr Government implemented a radical program of municipal mergers in NSW, centred largely on non-metropolitan councils.

In this paper our analysis of KPMG's (2016) Outline of Financial Modelling Assumptions for Local Government Merger Proposals is divided into three main parts. Section 2 provides a synoptic account of Fit for the Future reform process in NSW local government by way of institutional background. Section 3 critically examines the KPMG (2016) report. The paper ends with some brief concluding remarks in section 4.

\section{New South Wales Local Government Reform Process}

The largest of the seven Australian state and territory local government jurisdictions, NSW local government is currently comprised of 152 'general purpose councils', 12 'special purpose councils' as well as the NSW Aboriginal Land Council. NSW local authorities fall under a regulatory system made up of the NSW Office of Local Government (OLG), the NSW Independent Pricing and Regulatory Tribunal (IPART), NSW Boundaries Commission (when constituted), NSW Local Government Grants Commission and auxiliary bodies, together with the NSW Local Government Act (1993) as amended. NSW local government is a 'creature of statute' in common with other Australian local government systems, given that the NSW Government possesses extensive regulatory powers over local councils.

In comparison with most other developed nations, local government in Australia performs a limited range of functions, focused largely on 'services to property'. In contrast to most other local government systems, it does not provide many 'services to people', such as education and policing, which are run by state and territory governments. NSW local government is funded through property taxes, fees and charges for services, intergovernmental grants, developer charges and various other minor sources. NSW local authorities deliver local infrastructure, including local roads, and local services, such as sewage and solid waste disposal, with some regional councils operating local water 
utilities. NSW local councils fall under elected councillors and (typically) indirectly elected mayors, who face four-year electoral cycles. The operational aspects of councils are run by a general manager who oversees a professional bureaucracy.

The Fit for the Future NSW local government reform process has its origins in the Destination 2036 Workshop held on $19^{\text {th }}$ August 2011 in the regional centre of Dubbo held under (then) Minister for Local Government Don Page. It was attended by local government councillors and general managers from all NSW local authorities. Destination 2036 led to the formation of the Independent Local Government Review Panel (ILGRP) and the Local Government Acts Taskforce. Given an election promise of 'no forced amalgamation' by the incoming Coalition government, the Panel's terms of reference precluded forced mergers. In April 2013, the ILGRP released its interim report entitled Future Directions for NSW Local Government. Despite its terms of reference, in Future Directions, the Panel (2013a, p.48) proposed extensive council mergers, but largely concentrated on Greater Sydney. Future Directions (2013a, p 5) recommended that the NSW Government 'reduce the number of councils in the Sydney basin to around 15, and create major new cities of Sydney, Parramatta and Liverpool, each with populations of $600-800,000$ '. Despite assurances that it would follow 'evidence-based' policymaking, the Panel offered no empirical evidence in support of its compulsory municipal mergers recommendation.

Future Directions was widely attacked. Critics focused not only on the absence of empirical evidence for the proposed merger program, but also on the quality of the little commissioned research used by the Panel. Assessing Processes and Outcomes of the 2004 Local Government Boundary Changes in NSW by Jeff Tate Consulting (2013) drew scathing commentary for relying entirely on discussions with people from only five of the 27 councils amalgamated in 2004 (Drew and Dollery, 2016), instead of comparing the post-consolidation performance of merged and unmerged councils in the same municipal classification categories against the NSW Government 
Comparative Information on NSW Local Government Councils data and/or the TCorp (2013) financial ratios, subsequently readjusted as Fit for the Future performance indicators.

After a round of public consultation, the Panel submitted its final report Revitalising Local Government in October 2013. The chief dissimilarities between Future Directions and Revitalising Local Government lay in a shift in emphasis on the proposed process for merging councils. Instead of outright compulsion, Revitalising Local Government proposed that a 'strengthened' Boundaries Commission evaluate merger proposals and make binding recommendations. This process approximated existing provisions in the NSW Local Government Act (1993).

However, in common with Future Directions, Revitalising Local Government still claimed that municipal mergers were vital as a means of improving NSW local government without furnishing any empirical evidence. Various other similarities between Future Directions and Revitalising Local Government are striking. For example, in its assessment of NSW local government financial sustainability, Future Directions (2013a, p. 6) noted that 'it is also clear that the financial base of the sector is in urgent need of repair', observing that 'put simply, there are too many councils chasing too few resources'. Revitalizing Local Government echoed this slogan, with the Panel (2013b, p. 720) claiming that 'NSW simply cannot sustain 152 councils'.

The NSW Government only released Revitalising Local Government in January 2014. After the resignation of Premier O'Farrell in April 2014, incoming Premier Baird replaced Minister Page with Minister Toole as Minister for Local Government. This Cabinet reshuffle may account for the fact that the NSW Government only publically responded to Revitalising Local Government in September 2014 by launching its Fit for the Future (OLG, 2014b; 2014c) reform package.

All of the council mergers recommended by the Panel were accepted by Fit for the Future, which offered no further empirical evidence. Fit for the Future laid out a 'self-assessment' procedure by 
which each local authority would evaluate itself against a number of performance indicators. Local councils were obliged to submit 'merge' and/or 'stand-alone' proposals to the OLG by 30 June 2015. In terms of the initial Fit for the Future procedure, proposals would be judged by an Expert Panel. However, on 27 April 2015 the Minister Toole declared that IPART, augmented by commercial consultant John Comrie, would constitute an 'Expert Advisory Panel' to assess council submissions. The Minister simultaneously released Methodology for Assessment of Council Fit for the Future Proposals: Local Government Consultation Paper April 2015. This document indicated that IPART would assess local council submissions using criteria different from the earlier Fit for the Future criteria. Methodology for Assessment of Council Fit for the Future Proposals called for submissions on its suggested criteria.

On 5 June 2015, IPART (2015b) released Methodology for the Assessment of Council Fit for the Future Proposals, only 25 days from the 30 June 2015 deadline for council submissions under the Fit for the Future. Methodology for the Assessment of Council Fit for the Future Proposals set out IPART's response to submissions on Methodology for Assessment of Council Fit for the Future Proposals, in conjunction with its final assessment criteria.

The NSW OLG's Fit for the Future program had been based on seven criteria which local authorities were obligated to address in submissions to the OLG. However, by changing these criteria Methodology for the Assessment of Council Fit for the Future Proposals at a stroke rendered obsolete much of the Fit for the Future program on which local authorities had expended considerable resources. In particular, the Fit for the Future criteria were supplanted by new measures in Methodology for Assessment of Council Fit for the Future Proposals, together with an overarching 'adequate scale and capacity' criterion.

Given the harsh time constraints, Methodology for Assessment of Council Fit for the Future Proposals placed NSW local government in invidious circumstances. Prior to its release, local 
authorities across NSW had spent considerable effort consulting with local communities and preparing 'merge', 'stand-alone' and 'rural council' proposals on the basis of the Fit for the Future process and its assessment criteria. These exertions were now rendered irrelevant. Furthermore, too little time remained for local authorities to repeat (a) a thorough community engagement process and (b) prepare submissions using the new Methodology for Assessment of Council Fit for the Future Proposals. In addition, the new IPART (2015b) assessment criteria and benchmarks were seriously flawed (USU, 2015).

On 20th October 2015, IPART (2015c) released its Assessment of Council Fit for the Future Proposals with its decisions on the fate of individual local councils. In all, IPART (2015c) considered 139 local council submissions from a total of 144 councils, encompassing four 'merger' proposals (concerning nine municipalities), 115 'council improvement' proposals and twenty 'rural council' proposals. Under an earlier Panel recommendation, eight Far West NSW shires had not been obligated to submit proposals.

In sum, IPART assessed $52(37 \%)$ proposals as 'fit for the future' and $87(63 \%)$ as not 'fit for the future'. Of the latter group, 60 councils were deemed not to have adequate 'scale and capacity' but met the financial criteria, 18 had sufficient 'scale and capacity' but were not financially 'fit', and nine had both inadequate 'scale and capacity' and failed on financial criteria. All four 'merger' proposals were assessed as 'fit for the future' (IPART, 2015c).

On $18^{\text {th }}$ December 2015, the NSW Government announced its decision on municipal mergers. It recommended the creation of 35 local councils through forced mergers. Fifteen of these amalgamations were in Greater Sydney, reducing the number of Sydney councils from 43 to 25. The remaining 20 councils were in regional NSW, decreasing country councils from 109 to 87 . It is striking that little correspondence exists between the IPART (2015c) determinations on specific local authorities and the 35 councils proposed for amalgamation by the NSW Government. It has been suggested that political considerations played a major role in the NSW Government decisions. 
Minister Toole (2015) claimed that "each proposal was the result of careful consideration of all the evidence, including four years of consultation with every council in NSW, independent assessments, merger preferences submitted by councils, and feedback communities and stakeholders'. He observed that - under the Local Government Act (1993) - the 35 proposals would be examined by appointed Delegates, through a public consultation process, and then referred to Boundaries Commission for final recommendations. In terms of the Local Government Act (1993), the Minister is not obliged to accept these recommendations and retains the final decision.

In January 2016, the NSW Government published a brief 'merger proposal' for each of the 35 proposed municipal mergers which summarised the purported benefits attendant upon amalgamation, including estimates of pecuniary savings from 2020 onwards. These estimates were developed by KPMG (2015) in its Local Government Reform: Merger Impacts and Analysis. According to the NSW Government, KPMG (2015) had demonstrated that savings would primarily flow from the 'removal of duplicate back office and administrative functions', the 'streamlining of senior management roles', increased purchasing power for 'materials and contracts', and lower outlays on councillor fees.

However, the NSW Goyernment refused to release Local Government Reform, even to Delegates assessing specific merger proposals, classifying it as 'Cabinet in confidence'. Instead, under intense political pressure, it released KPMG's (2016) Outline of Financial Modelling Assumptions for Local Government Merger Proposals Technical Paper ${ }^{1}$. In this document KPMG (2016) set out in the methodology employed by KPMG (2015) in its Local Government Reform: Merger Impacts and Analysis. We now consider in detail Outline of Financial Modelling Assumptions for Local Government Merger Proposals Technical Paper.

\section{Evaluation of KPMG (2016) Methodology}

\footnotetext{
${ }^{1}$ The Baird Government even voted down a Parliamentary motion calling for the release of KPMG (2015) and other documents related to the forced amalgamation program on 25 February 2016.
} 


\subsection{Generic Problems with KPMG (2016) Methodology}

Three major generic problems are evident in Outline of Financial Modelling Assumptions for Local Government Merger Proposals Technical Paper. In the first place, no verifiable empirical evidence is provided in support of claims on savings expected to arise from specific municipal mergers. In most cases, savings are simply claimed with no effort made to justify why these dollars values (or percentage equivalents) were chosen. Without evidence that similar savings have been achieved in other Australian state jurisdictions, or indeed in the 2004 NSW amalgamation program, the KPMG (2016) assumptions are simply guesswork. In the absence of any credible evidence that similar savings have been achieved in previous mergers, there is thus no reason for the public to have any confidence in the KPMG (2015) modelling.

KPMG ignored the most relevant empirical evidence on the potential savings arising from NSW amalgamations which derives from the financial data subsequent to the March 2008 Queensland forced mergers. Unfortunately, because the Queensland amalgamations occurred part way through a financial year it is not possible to generate reliable and comparable evidence of initial savings in employee expense. However, it is possible to track the audited financial data to ascertain (a) whether it is reasonable to expect large reductions in employee expenses following the three-year moratorium after forced amalgamations and (b) whether initial savings in staff expenditure might have been eroded by subsequent higher rates of growth amongst the merged cohort of councils. It is important to note that Queensland also employed a moratorium on forced redundancies for the first three years.

Table 1 provides details of the mean annualised growth in staff expenditure disaggregated into 'amalgamated' and 'non-amalgamated' cohorts of Queensland councils. The periods cited are the financial years and all rows relate to the average annualised rate of growth since the end of the 2009 financial year. Thus, the last row contains six periods of growth. Growth is presented in nominal terms in order to avoid possible errors in inflating the data ${ }^{\mathrm{i}}$.

\section{TABLE 1 COMES HERE}


It is thus clear that there is no sound reason to expect a significant and enduring reduction in staff expenditure after the expiration of the moratorium on forced redundancy. Moreover, it is obvious that the average annualised rate of growth for the amalgamated cohort has been greater than that of the non-merged cohort for all of the years in Table 1 and this difference shows no sign of dissipating. It is thus most unlikely that additional savings assumed by KPMG will occur after the moratorium on forced amalgamation. We also note that s218CA(2) of the Local Government Act (1993) seems to impose enduring constraints on staff redundancies in rural centres, which makes the assumed savings even less likely. In addition, the evidence from the audited financial statements of Queensland councils seems to suggest that initial savings arising from the termination of senior management may well be eroded by faster annualised rates of growth in employee expenditure over the foreseeable future.

Secondly, Outline of Financial Modelling Assumptions for Local Government Merger Proposals Technical Paper is replete with errors and inconsistencies. Problems include inconsistencies with recent KPMG reports on NSW local government, incompatibilities with official reports, like the Local Government Remuneration Tribunal Report, errors of logic, gross oversimplifications and errors in data selection. It is especially troubling that the KPMG assumptions have been applied to the very broad categories of 'metropolitan' and 'regional' councils. Not only is this inaccurate (see Drew and Dollery, 2014), but the NSW Office of Local Government time series data employs 11 categories. These categories are applied by the NSW Local Government Grants Commission to calculate an isolation allowance specific to each non-metropolitan council. Furthermore, the NSW Local Government Remuneration Tribunal employs nine different categories.

A noteworthy error in KPMG (2016) resides in the fact that KPMG (2016, p.7) appears to have based its costings for redundancies flowing from mergers on the Commonwealth Fair Work Act 2009 National Employment Standards termination pay schedule. However, NSW local government falls under the Local Government (State) Award 2014 and its redundancy provisions. This makes a 
substantial difference to the costings. For example, under the Commonwealth Fair Work Act 2009, an employee with ten or more years' service is entitled to 12 weeks' pay, whereas under the NSW Local Government (State) Award 2014 the same employee will receive 34 weeks' pay or $183 \%$ more. Given the substantial impost of redundancy costs following the three-year post-merger employment protection period, this means that KPMG (2016) has severely under-estimated the costs of amalgamation.

Finally, quite apart from these errors and inconsistences, Outline of Financial Modelling Assumptions for Local Government Merger Proposals Technical Paper is noteworthy for its neglect of important cost considerations. For example, as we show in Table 2 below, KPMG (2016) have ignored the post-merger costs of service equalisation across the local authorities which have been merged. It is well known that significant differences exist in the level and quality of service delivery in NSW local government between different councils, even those in the same NSW Office of Local Government council classification category. As experience in the 2008 Queensland amalgamation program has demonstrated, post-merger service provision is typically equalised upwards and this carries substantial costs. It should be stressed that service harmonisation of this kind applies to all services in the amalgamated council since it is hard to justify employing a common rating system with differentiated service levels. For example, Dallinger (2014) examined the newly merged Moreton Bay Regional Council and showed inter alia that - across the board - local services had been adjusted upwards in the new entity. Ignoring these costs means that the KPMG (2015) calculations substantially understate the costs of amalgamation.

\subsection{Specific Problems with KPMG (2016) Methodology}

In addition to these generic problems with an Outline of Financial Modelling Assumptions for Local Government Merger Proposals Technical Paper, it is possible to identify a host of specific problems. In order to economize on space constraints, we examine these specific problems in Table 2 below: 
Table 2: Specific Problems with KPMG (2016) Methodology

\begin{tabular}{|c|c|}
\hline KPMG Assumption & Comment \\
\hline $\begin{array}{l}\text { Failure to Model Financial } \\
\text { Assistance Grants (FAGs) } \\
\text { Changes }\end{array}$ & $\begin{array}{l}\text { Financial Assistance Grants (FAGs) are only subject to } \\
\text { constraints imposed as a result of the } 7 \text { February } 2006 \\
\text { proclamation under subsection 6(4) of the } \\
\text { Commonwealth legislation for a period of four years. } \\
\text { The KPMG (2016) modelling does not appear to respond } \\
\text { to the Local Government (Financial Assistance) Act } \\
\text { (1995) (CTH) in any way. } \\
\text { This is disturbing given that FAGs account for around a } \\
\text { tenth of council revenue on average. Failure to model } \\
\text { changes to FAGs risks over-estimating revenue (after } \\
\text { four years) and thus over-estimating the savings arising } \\
\text { from the mergers. }\end{array}$ \\
\hline \multicolumn{2}{|l|}{$\begin{array}{l}\text { Treatment of Councils that are } \\
\text { Split in a Merger }\end{array}$} \\
\hline $\begin{array}{l}\text { 'A council that is split has its } \\
\text { financial statements... split on } \\
\text { a per capita basis' (KPMG, } \\
2016, \text {.p. } 8 \text { ) }\end{array}$ & $\begin{array}{l}\text { This is an entirely inequitable method of dividing assets } \\
\text { with the potential to lead to unanticipated deleterious } \\
\text { outcomes (see Drew and Dollery, 2014a). Indeed, the } \\
\text { inequitable division of assets resulted - in part - in acute } \\
\text { fiscal stress for breakaway councils in the Delatite Shire } \\
\text { de-amalgamation in Victoria and the subsequent } \\
\text { Queensland demergers. }\end{array}$ \\
\hline $\begin{array}{l}\text { 'Councils that are part of a } \\
\text { merger but lose a portion of its } \\
\text { area to another merger cluster } \\
\text {... will have its financial } \\
\text { statement adjusted to reflect } \\
\text { reduced revenue/expenditure } \\
\text { profile. These adjustments are } \\
\text { generally made on a per capita } \\
\text { basis' (KPMG, 2016, p.8). }\end{array}$ & $\begin{array}{l}\text { This is the entirely fallacious method for adjusting } \\
\text { revenue and expenditure. Rates are not levied on a per } \\
\text { capita basis, but on a per assessment basis. Thus, the } \\
\text { major portion of revenue apportionment must clearly be } \\
\text { conducted on a per assessment basis. This data is readily } \\
\text { available from the NSW OLG Time Series data. } \\
\text { Moreover, as demonstrated by Drew and Dollery } \\
\text { (2014b), the relevant functional unit for municipal } \\
\text { expenditure analysis is the number of assessments, not } \\
\text { absolute population which is erroneously employed by } \\
\text { KPMG (2016). }\end{array}$ \\
\hline \multicolumn{2}{|l|}{$\begin{array}{l}\text { Savings from Materials and } \\
\text { Contracts Expenditure }\end{array}$} \\
\hline $\begin{array}{l}\text { KPMG claim that 'savings' will } \\
\text { apply to } 80 \% \text { of the category } \\
\text { 'Materials and Contracts }\end{array}$ & $\begin{array}{l}\text { No evidence is provided to support these 'assumptions'. } \\
\text { KPMG (2016) implicitly assumes that amalgamating }\end{array}$ \\
\hline
\end{tabular}




\begin{tabular}{|c|c|}
\hline $\begin{array}{l}\text { Expenditure' and will be } \\
\text { 'phased in' over } 3 \text { years. }\end{array}$ & $\begin{array}{l}\text { councils have not entered into long-term contracts for } \\
\text { the receipt of materials and services (or that the services } \\
\text { are not already the subject of larger regional } \\
\text { collaborations). Furthermore, there is no justification } \\
\text { provided for the staged implementation of savings from } \\
\text { 'materials and contract expenditure'. The net effect of } \\
\text { these assumptions is to overestimate savings. }\end{array}$ \\
\hline $\begin{array}{l}\text { Value of efficiency saving } \\
\text { assumed to be } 3 \% \text { for } \\
\text { metropolitan councils and } 2 \% \\
\text { for regional councils. }\end{array}$ & $\begin{array}{l}\text { No empirical evidence is provided to support of these } \\
\text { assumptions. Moreover, in its other reports for NSW } \\
\text { councils, KPMG has used different assumptions. For } \\
\text { example, in its Bombala Council, Cooma-Monaro Shire } \\
\text { Council and Snowy River Shire Council Merger } \\
\text { Business Case (1 May 2015), KPMG stated that 'a } 1.5 \\
\text { per cent saving on Materials and Contract expenses has } \\
\text { been applied' (KPMG, 2015, p.21). } \\
\text { KPMG needs to explain why its present estimate differs } \\
\text { from the estimate provided by it just eight months } \\
\text { earlier. } \\
\text { In addition, Ernst and Young (2015) report that the } \\
\text { KPMG analysis of Pittwater and Manly assumed a } \\
\text { materials and contracts efficiency of } 2 \% \text { (and not } 3 \% \text { ). } \\
\text { Moreover, other for-profit consultants have used } \\
\text { different values in NSW. Thus, Morrison and Low } \\
\text { employ a number of different assumptions for } \\
\text { efficiencies derived from materials and contracts which } \\
\text { range from } 1 \% \text { through to 5\%. There is thus no clear } \\
\text { consensus on the likely savings in this expenditure } \\
\text { category. } \\
\text { Finally, if savings are possible in the procurement of } \\
\text { materials and contracts and KPMG (2016) is correct in } \\
\text { asserting that savings 'are subject to scale', then it } \\
\text { follows that a system of centralised procurement for the } \\
\text { entire state - along the lines employed in Queensland by } \\
\text { the Queensland Local Government Association (LGAQ) } \\
\text { - would produce far greater savings than any single } \\
\text { amalgamation. Moreover, councils not subject to } \\
\text { amalgamation would be able to share in KPMG's ( } 2016 \text { ) } \\
\text { assumed savings. State-wide procurement thus } \\
\text { represents a far superior method of realising these } \\
\text { savings than expensive mergers. }\end{array}$ \\
\hline Savings from Councillor & \\
\hline
\end{tabular}




\begin{tabular}{|c|c|}
\hline$x p$ & \\
\hline $\begin{array}{l}\text { KPMG }(2016, p .2) \text { notes that } \\
\text { 'the number of councillors for a } \\
\text { new merged entity mirror the } \\
\text { highest number of councillors } \\
\text { that currently exist in any one } \\
\text { of the councils participating in } \\
\text { the merger'. }\end{array}$ & $\begin{array}{l}\text { This statement does not reflect the maximum number of } \\
\text { councillors allowable under the Local Government Act } \\
\text { (1993). Thus KPMG (2016) is asserting that there will } \\
\text { be a reduction in the level of democratic representation } \\
\text { for merged councils. Moreover, this procedure for } \\
\text { determining the number of councillors will inevitably } \\
\text { lead to very disparate levels of democratic representation } \\
\text { between merged and unmerged councils. }\end{array}$ \\
\hline $\begin{array}{l}\text { KPMG (2016, } \\
\text { 'this figure is } g \\
\text { standard wage } \\
2.3 \text { per cent ove }\end{array}$ & $\begin{array}{l}\text { This is inconsistent with the } 2015 \text { Local Government } \\
\text { Remuneration Tribunal determination. The NSW } \\
\text { Remuneration Tribunal }(2015, \text { p. 14) made the following } \\
\text { observation: 'the Tribunal has reviewed the key } \\
\text { economic indicators, including the Consumer Price } \\
\text { Index and Wage Price Index, and finds that the full } \\
\text { increase of } 2.5 \text { per cent available to it is warranted'. }\end{array}$ \\
\hline $\begin{array}{l}\text { KPMG }(2016 \\
\text { 'this [sic] savi } \\
\text { the assumptio } \\
\text { elected counc } \\
\text { regional) will } \\
\$ 30,000 \text { per a }\end{array}$ & $\begin{array}{l}\text { The most recent determination for councillor and } \\
\text { mayoral fees includes nine different rates (depending on } \\
\text { the categorisation of council in the NSW OLG } \\
\text { classification system). For instance, 'county councils } \\
\text { other' councillor fees are set at a minimum of } \$ 1,660 \\
\text { and a maximum of } \$ 5,490 \text {. The 'county council other' } \\
\text { mayoral fees range from a minimum of } \$ 3,550 \text { through } \\
\text { to a maximum of } \$ 10,020 \text {. } \\
\text { By way of contrast, councillor fees for 'principal city' } \\
\text { councils range from } \$ 25,040 \text { through to } \$ 36,720 \text {, whilst } \\
\text { mayoral fees for the same category range from } \$ 153,200 \\
\text { through to } \$ 201,580 \text {. } \\
\text { It should thus be clear that an assumption of } \$ 30,000 \text { for } \\
\text { every council is deeply flawed. Moreover, KPMG } \\
\text { (2016) has not attempted to differentiate between } \\
\text { savings relating to mayors as opposed to councillors. }\end{array}$ \\
\hline $\begin{array}{l}\text { Savings from Reduced } S \\
\text { and Wage Expenditure }\end{array}$ & \\
\hline $\begin{array}{l}\text { KPMG (2016, p. 3) notes that } \\
\text { 'staffing reductions are } \\
\text { assumed to occur gradually } \\
\text { with a modest level of } \\
\text { voluntary attrition in the first } \\
\text { three years of amalgamation'. }\end{array}$ & $\begin{array}{l}\text { No empirical evidence is provided by KPMG (2016) to } \\
\text { support this claim. } \\
\text { In fact, as we have seen from the } 2008 \text { Queensland } \\
\text { merger process in section } 3.1 \text { above, total staff } \\
\text { expenditure for the amalgamated cohort of councils in } \\
\text { Queensland rose for each of the three full financial years }\end{array}$ \\
\hline
\end{tabular}




\begin{tabular}{|c|c|}
\hline & $\begin{array}{l}\text { following the } 2008 \text { amalgamations. This is clear from } \\
\text { evidence obtained from audited financial statements of } \\
\text { each of the affected councils, in addition to the } \\
\text { Queensland Department of Infrastructure and Planning } \\
\text { Queensland Local Government Comparative } \\
\text { Information 2008-2009. } \\
\text { Moreover, the average annualised rate of growth in staff } \\
\text { expenditure for the amalgamated cohort in Queensland } \\
\text { (7.795\% p.a.) was far higher than that of the non- } \\
\text { amalgamated cohort (6.031\% p.a.) in nominal terms for } \\
\text { the first three full financial years. }\end{array}$ \\
\hline $\begin{array}{l}\text { KPMG (2016) claims there will } \\
\text { be savings from Tier } 4 \text { and Tier } \\
3 \text { positions }\end{array}$ & $\begin{array}{l}\text { KPMG (2016) do not state what rate of savings was used } \\
\text { for these senior management positions. However, given } \\
\text { that General Manager and Director entitlements are the } \\
\text { subject of individually negotiated contracts, it is highly } \\
\text { unlikely that modelling employing a single rate of } \\
\text { savings would be in any way satisfactory or reflective of } \\
\text { what will occur in a specific merger. }\end{array}$ \\
\hline $\begin{array}{l}\text { KPMG (2016, p. } 3) \text { claim that } \\
\text { 'overall staffing efficiencies } \\
\text { were estimated at } 7.4 \text { per cent } \\
\text { for metropolitan mergers... } \\
\text { [and] } 3.7 \text { to } 5 \text { per cent' for } \\
\text { regional councils'. }\end{array}$ & $\begin{array}{l}\text { No evidence has been provided by KPMG (2016) to } \\
\text { support this critical claim. } \\
\text { The efficiency estimate for regional councils ( } 3.7 \text { to } 5 \\
\text { per cent) by KPMG (2016) in January } 2016 \text { differs } \\
\text { markedly from the estimate provided by KPMG (2015, } \\
\text { p.21) to Snowy River, Bombala and Cooma-Monaro } \\
\text { 'estimated to be approximately } 6 \text { per cent on a FTE } \\
\text { basis'. } \\
\text { KPMG should explain why this estimate has changed so } \\
\text { markedly in the past eight months. } \\
\text { Actual empirical evidence based on the entire cohort of } \\
\text { Queensland councils suggests that little or no } \\
\text { efficiencies relating to employee costs can be reasonably } \\
\text { expected. Based on seven full financial years of data } \\
\text { following the Queensland mergers, the average } \\
\text { annualised rate of growth in employee expense is far } \\
\text { higher for the amalgamated cohort ( } 4.997 \% \text { p.a.) than } \\
\text { the non-amalgamated cohort ( } 3.724 \% \text { p.a.). In making } \\
\text { these calculations, we have not made any claims about } \\
\text { initial savings made as a result of terminating senior } \\
\text { appointments. Our data relates to the rate of change in } \\
\text { employee expense for the full financial years following } \\
\text { amalgamation. Queensland also had a moratorium on }\end{array}$ \\
\hline
\end{tabular}




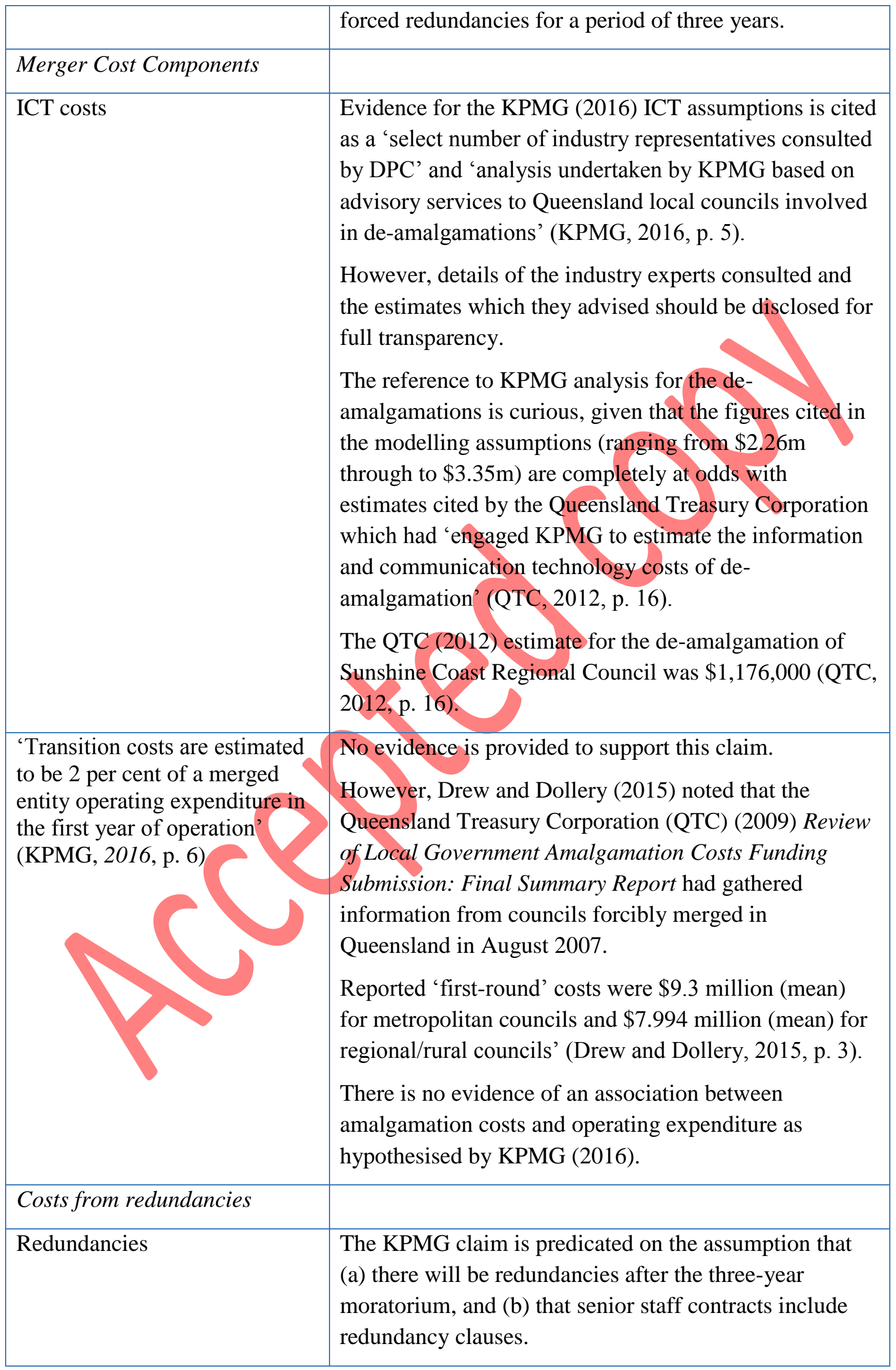




\begin{tabular}{|c|c|}
\hline & $\begin{array}{l}\text { However, this claim appears to ignore the constraints } \\
\text { imposed on redundancies for rural centres outlined in } \\
\text { s218CA(2) of the Local Government Act (1993). } \\
\text { Empirical evidence from the Queensland amalgamations } \\
\text { calls into question assumptions regarding redundancies } \\
\text { (see discussion above on Savings from Reduced Salary } \\
\text { and Wage Expenditure). }\end{array}$ \\
\hline $\begin{array}{l}\text { KPMG (2016, p. 7) claimed } \\
\text { that 'based on established } \\
\text { practices and the average tenure } \\
\text { for the sector, the redundancy } \\
\text { payment would be provided for } \\
\text { sixteen (16) weeks'. Reference } \\
\text { is then made to the 'Fair Work } \\
\text { Ombudsman (2014), } \\
\text { Redundancy pay and } \\
\text { entitlements schedule'. }\end{array}$ & $\begin{array}{l}\text { As we have demonstrated in section } 2 \text { (iv), local } \\
\text { Government general staff in NSW are covered by the } \\
\text { Local Government (State) Award, not a federal award as } \\
\text { apparently 'assumed' by KPMG. Employees are entitled } \\
\text { to up to } 34 \text { weeks of pay (for employees of } 10 \text { years } \\
\text { standing or higher) on a scale associated with the } \\
\text { number of years of service. } \\
\text { An assumption of } 16 \text { weeks (equivalent to the } \\
\text { entitlement of an employee with } 4 \text { to } 5 \text { years of service } \\
\text { in terms of the table on redundancy entitlements in NSW } \\
\text { Local Government (State) Award } 2014 \text {, p.308) is a gross } \\
\text { oversimplification. It amounts to an assumption that the } \\
\text { average person laid off has a period of service of just } \\
\text { over } 4 \text { years. This does not reflect the reality of local } \\
\text { government employment in NSW, especially in country } \\
\text { councils, where employees typically have long periods }\end{array}$ \\
\hline
\end{tabular}

It is apparent from Table 2 that the analysis in KPMG (2016) is flawed in a number of respects. Perhaps most concerning is that the authors of KPMG (2016) seem unaware of a number of fundamental characteristics of Australian (and NSW) local government. For example, it is decidedly odd that KPMG (2016) was oblivious to the freeze on FAGs, determinations by the Local Government Remuneration Tribunal, and the NSW Local Government (State) Award. In addition, it is puzzling that KPMG (2016) is inconsistent with recent other reports undertaken by KPMG on NSW councils, as in the Bombala Council, Cooma-Monaro Shire Council and Snowy River Shire Council Merger Business Case (KPMG, 2015). Finally, it is obvious that KPMG is not aware of the substantial empirical literature on Australian local government amalgamations, such as Drew and Dollery (2015) on the transformation costs of mergers.

\section{Conclusions}


Two major conclusions flow from our analysis. Firstly, we have demonstrated that the methodology provided in KPMG (2016) is deeply flawed. It follows that the analyses of all of the specific mergers which have been examined by KPMG (2015) in its Local Government Reform: Merger Impacts and Analysis using this methodology are thus grossly inaccurate and do not reflect the true costs and benefits involved. Given that the estimates provided by KPMG for all the recommended mergers are erroneous and greatly inflate the financial benefits involved, it is assuredly the case that controversial and divisive mergers cannot be prescribed on the basis of demonstrably false financial estimates.

Secondly, the analysis in this paper supports concerns expressed in the literature, such as Howlett and Migone (2013), regarding reliance on policy analysis undertaken by commercial consultants. The methodology set out in KPMG (2016) demonstrably overstates the financial benefits contingent on the proposed municipal mergers, thereby deliberately bolstering the case for amalgamation. Misgivings over the use of the estimates provided by the 'cost/benefit summaries' of KPMG's (2015) Local Government Reform: Merger Impacts and Analysis have been amplified by the fact that the NSW Government has flatly refused to release the full report and has terminated attempts at debating its merits in the NSW Parliament.

More generally, various options could be considered to ameliorating concerns over the policy advice provided by commereial consultants. For example, more than a single commercial consultant could be contracted to provide advice on a given policy question. Similarly, in addition to policy advice from for-profit consultants, public agencies could simultaneously arrange for 'in-house' advice to be sought on the same matter. Furthermore, steps could be taken to augment existing 'in-house' policy expertise by employing specialist skills. Under all of these options, policymakers would not have to rely on a single source of advice.

\section{Notes}

${ }^{1}$ The problem with using real rather than nominal data centers around inflating and selecting an appropriate index. National CPI relates to a proscribed basket of goods and services, many of which are not used by local government and 
thus possess little relevance. By contrast, local government cost indexes are an estimate only, based on an amalgam of ABS indexes which may not be reflective of actual municipal costs. For instance one component of the Queensland local government cost index is the CPI in Brisbane. In addition, no effort is made in either type of index to identify different cost pressures specific to particular regions. Given that we are interested in comparing the growth in expenses between two stable cohorts over a number of years, there is in any event no need to inflate data. Apart from the problems of identifying a suitable index, inflating data would also introduce avoidable rounding error.

\section{References}

Abelson, P. and Joyeux, R. (2015), 'Smoke and mirrors: Fallacies in the New South Wales government's views on local government financial capacity', Public Money \& Management, 35(4), 315-320.

Bevir, M. and Rhodes, R. A. W., (2001), 'Decentering tradition: Interpreting British government', Administration \& Society, 33(2), 107-132.

Boston, J. (1994), 'Purchasing policy advice: The limits of contracting out', Governance, 7(1), 1-30. Commonwealth of Australia (1995), Local Government (Financial Assistance) Act (1995).

J. Craft and Howlett, M. (2013), 'The dual dynamics of policy advisory systems: The impact of externalization and politicization on policy advice', Policy and Society, 32(3), 187-197.

Dallinger, D. (2014), Amalgamation in Queensland: A Case Study of the Moreton Bay Regional Council, unpublished PhD thesis, Armidale: University of New England.

Deloitte Access Economics (DAE) (2011), Local Government Structural Reform in Tasmania, Hobart: Property Council of Australia.

Department of Infrastructure and Planning (2009), Queensland Local Government Comparative Information 2008-09, Brisbane: Department of Infrastructure and Planning.

Dolfsma, W. (2013), Government Failure, Edward Elgar Publishers, Cheltenham.

Dollery, B. E., Grant, B. and Kortt, M. (2012), Councils in Cooperation, Federation Press, Sydney.

Dollery, B. E., Kortt, M. A. and De Souza, S. (2015), 'Policy Analysis Capacity and Australian Local Government', in B. Head and K. Crowley (eds.), Policy Analysis in Australia, Bristol: Policy Press, 105-120.

Drew, J., Kortt, M. and Dollery, B. E. (2013), 'A Cautionary Tale: Council Amalgamation in Tasmania and the Deloitte Access Economics Report', Australian Journal of Public Administration, 72(1), 55-65. 
Drew, J. and Dollery, B. (2014a), 'What's In a Name? Assessing the Performance of Local Government Classification Systems', Local Government Studies, DOI:

$10.1080 / 03003930.2015 .1007132$

Drew, J. and Dollery, B.E. (2014b), 'Keeping It In-House: Households as an Alternative Proxy for Local Government Output', Australian Journal of Public Administration, 73(2), 235-246.

Drew, J. D and Dollery, B. E. (2014c), 'The Impact of Metropolitan Amalgamations in Sydney on Financial Sustainability', Public Money and Management, 34(4), 281-288.

Drew, J. and Dollery, B. E. (2016), 'Less Haste More Speed: The Fit for the Future Reform Program in New South Wales Local Government', Australian Journal of Public Administration, 75(1), 78-88. Drew, J. and Dollery, B.E. (2015), 'Breaking Up is Hard to Do: The De-amalgamation of Delatite Shire', Public Finance and Management, 15(1), 1-23.

Dur, R. and Staal, K. (2008), 'Local Public Good Provision, Municipal Consolidation, and National Transfers', Regional Science and Urban Economics, 38, 160-73.

Ernst and Young (2015), Fit for the Future: Review of Business Case Estimates of Merger Net Benefits for Sydney Metropolitan Councils IPART Confidential Report October 2015, Ernst and Young: Sydney.

Independent Local Government Review Panel (ILGRP) (2013a), Future Directions of NSW Local Government - Twenty Essential Steps, Independent Local Government Review, Sydney.

Independent Local Government Review Panel(ILGRP) (2013b), Revitalising Local Government, ILGRP, Sydney.

Independent Pricing and Regulatory Tribunal (IPART) (2015a), Methodology for Assessment of Council Fit for the Future Proposals - Local Government Consultation Paper April 2015, IPART: Sydney.

Independent Pricing and Regulatory Tribunal (IPART) (2015b), Methodology for Assessment of Council Fit for the Future Proposals, IPART: Sydney.

Independent Pricing and Regulatory Tribunal (IPART) (2015c), Assessment of Council Fit for the Future Proposals, IPART: Sydney.

Jeff Tate Consulting (2013), Assessing Processes and Outcomes of 2004 Local Government Boundary Changes in NSW, Jeff Tate Consulting, McLaren Vale.

KPMG (2015), Bombala Council, Cooma-Monaro Shire Council, Snowy River Shire Council Merger Business Case Report 1 May 2015, KPMG: Sydney.

KPMG (2015), Local Government Reform: Merger Impacts and Analysis, KPMG: Sydney. 
KPMG (2016), Outline of Financial Modelling Assumption for Local Government Merger Proposals - Technical Paper Prepared for the NSW Department of Premier and Cabinet, 19 January, 2016, KPMG: Sydney.

Gregory, R. and Lonti, Z. (2008), 'Chasing shadows? Performance measurement of policy advice in New Zealand Government Departments', Public Administration, 86(3), 837-856.

Halligan, J. (1995), 'Policy advice and the public sector', in B. Guy Peters and D. T. Savoie (eds.), Governance in a changing environment, Montreal: McGill-Queen's University Press, 138-172.

Howlett, M. and Migone, A. (2013), 'The search for substance: Externalization, politicization and the work of Canadian policy consultants 2006-2013', Central European Journal of Public Policy, 7(1). Local Government Remuneration Tribunal (2015), Annual Report and Determination 13 April 2015, Local Government Remuneration Tribunal: Sydney.

Mueller, D.C. (2003), Public Choice III, Cambridge University Press, Cambridge.

NSW Government (2016), Council Boundary Review. Available at:

https://www.councilboundaryreview.nsw.gov.au/

NSW Local Government Grants Commission (2015), 2014-15 Annual Report, NSW Local

Government Grants Commission: Sydney.

Office of Local Government (2014a), Comparative Information on NSW Local Government 2012/13, Office of Local Government: Sydney.

Office of Local Government (2014b), Becoming fit for The Future. Available at http://www.fitforthefuture.nsw.gov.au/for-councils.

Office of Local Government (OLG)(2014c), Fit for the Future - A Blueprint for the Future of Local Government, OLG, Sydney.

Office of Local Government (OLG) (2014d), Fit for the Future Self-Assessment Tool, OLG, Sydney. Office of Local Government (2015), 2013-14 Time Series Data, Office of Local Government: Sydney.

Parliament of New South Wales (1993), Local Government Act (1993).

Queensland Treasury Corporation (2012), De-amalgamation Analysis of Sunshine Coast Regional Council, QTC: Brisbane.

Sansom, M. (2016). 'Court Clash as Hold-out Councils Try to Sink Baird's Mergers'. Government News, 24 May, 2016.

Steiner, R. (2003), 'The Causes Spread and Effects of Inter-municipal Cooperation and Municipal Mergers in Switzerland', Public Management Review, 5(4), 551-71.

TCorp (2013), Financial Sustainability of the New South Wales Local Government Sector, Sydney: TCorp. 
Toole, P. (2015), Stronger Councils for Sydney and Regional NSW, NSW Government: Sydney. Vesely, A. (2013), 'Externalization of policy advice: Theory, methodology and evidence', Policy and Society, 32 (2013), 199-209.

Wallis, J. and Dollery, B. E. (1999), Market Failure, Government Failure, Leadership and Public Policy. Macmillan, London.

Weller, P. and Stevens, B. (1998), 'Evaluating policy advice: The Australian experience', Public Administration, 76(3), 579-589.

Wolf, C. (1989) Markets or Governments, MIT Press, New York.

\section{Tables}

Table 1: Queensland Employee Expense Mean Annual Change, 2009 to 2015 (standard deviation in parentheses)

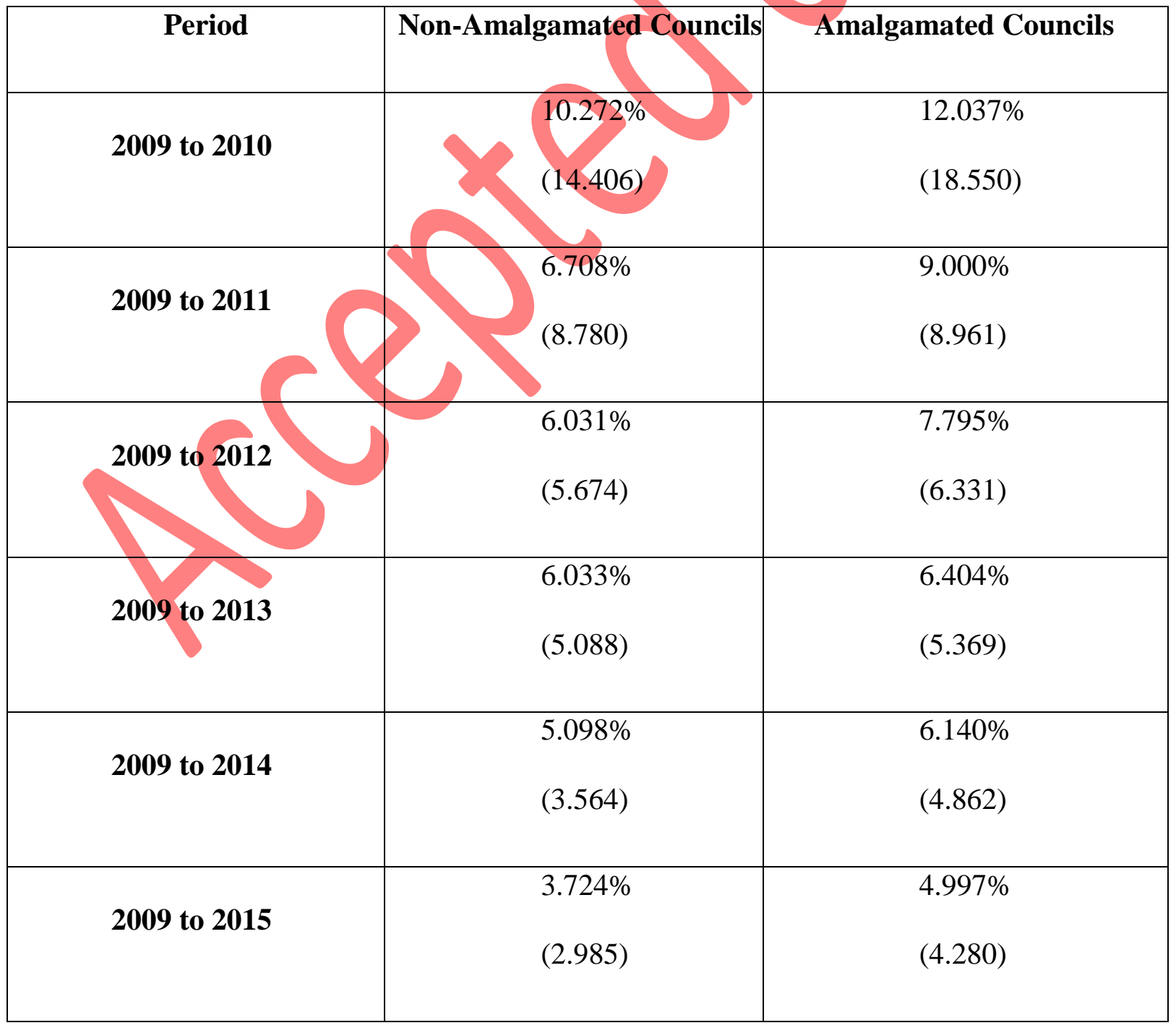


Source: 2009 data from Queensland Local Government Comparative Information 2008-09,

Department of Infrastructure and Planning 2010, verified to individual financial statements. All other years taken from audited financial statements. Data excludes four councils which were subsequently de-amalgamated. 